\title{
PEMBELAJARAN KONSEP IKATAN KIMIA DENGAN ANIMASI TERINTEGRASI LCD PROJECTOR LAYAR SENTUH (LOW COST MULTI TOUCH WHITE BOARD
}

\author{
Andri Agustina ${ }^{1}$ \\ MAN Insan Cendekia Paser \\ Jl. Negara KM 8 Tanah Grogot Kabupaten Paser Kalimantan Timur 76211 Indonesia \\ E-mail: agustina.andri3@gmail.com
}

\begin{abstract}
ABSTRAK
Ikatan kimia merupakan konsep yang penting untuk memahami berbagai topik dalam ilmu kimia. Konsep tersebut dinilai sulit dipelajari. Kesulitan tersebut terletak pada ketidakmampuan siswa mengorganisasikan level pengetahuan secara sistematis. Siswa tidak mampu memvisualisasikan level molekuler kemudian menghubungkannya dengan level makroskopik dan simbolik. Animasi pada tingkat molekuler dapat mendorong proses pembelajaran yang efektif. Pengintegrasian $\angle C D$ projector layar sentuh berbiaya murah digunakan untuk menciptakan komunikasi antara siswa-guru menjadi efektif. Pre-test dan post-test digunakan untuk mengetahui efektivitas penggunaan media animasi terintegrasi $\angle C D$ projector layar sentuh dalam pembelajaran konsep ikatan kimia. Hasil yang diperoleh menunjukan bahwa penggunaan media animasi dapat meningkatkan pemahaman dan minat belajar siswa pada konsep ikatan kimia.
\end{abstract}

Kata kunci: Ikatan kimia; animasi; $L C D$ projector layar sentuh.

\begin{abstract}
Chemical bonding concept is a fundamental and important concept to understand various topics in chemistry. It is considered difficult to learn. The difficulty lies inthe students inability to organize knowledge systematically. Students are not able to visualize the molecular level and then connect it to the macroscopic and symbolic level. Animation at the molecular level can encourage effective learning process. Integrated animation in low-cost multi-touch LCD projector is used to create effective students-teacher communication. Pre-test and post-test was used to determine the effectiveness of using Integrated animation in low-cost multi-touch $L C D$ projector in learning process. The results showed that the use of animation media can improve students attention and understanding in learning process.
\end{abstract}

Keywords: Chemical bonding; animation; touch-screen LCD projector. 


\section{PENDAHULUAN}

Perkembangan ilmu pengetahuan dan teknologi semakin mendorong upaya-upaya pembaharuan untuk memanfaatkan teknologi dalam proses pembelajaran, termasuk penggunaan alat atau media pembelajaran yang berbasis teknologi. Peran guru dituntut tidak hanya sekedar menggunakan media pembelajaran yang telah ada, namun lebih dari itu, harus mampu mengembangkan keterampilan membuat media pembelajaran yang akan digunakannya apabila media tersebut belum tersedia.

Ilmu kimia akan menjadi pengetahuan yang utuh manakala mampu menjelaskan fenomena kimia melalui tiga level representasi meliputi representasi makroskopik, submikroskopik dan simbolik (Jhonstone dalam Chittleborough et al, 2002). Konsep ikatan kimia merupakan konsep yang mendasar dan penting untuk memahami berbagai topik dalam ilmu kimia, juga memiliki ketiga level representasi tersebut. Berdasarkan hasil studi pendahuluan di MAN Insan Cendekia Paser terhadap 28 orang siswa kelas $\mathrm{X}$ semester I, menunjukan sebagian besar siswa mengalami kesulitan ketika diminta menjelaskan proses yang terjadi pada terbentuknya ikatan kimia. Kesulitan tersebut terletak pada ketidakmampuan siswa dalam mengorganisasikan ketiga level pengetahuan secara sistematis.

Media pembelajaran dapat memperjelas penyajian pesan dan informasi sehingga dapat memperlancar dan meningkatkan proses dan hasil belajar (Azhar,2002). Peran media pembelajaran sebagai alat bantu dapat menjembatani konsep abstrak seolah menjadi konkret melalui visualisasi. Salah satu teknik visualisasi adalah dengan menggunakan media komputer berupa animasi. Animasi pada tingkat molekuler dapat mendorong proses pembelajaran yang efektif (Tasker, 2006). LCD projector layar sentuh berbiaya murah adalah modifikasi LCD projector yang digunakan untuk menciptakan komunikasi yang efektif, tidak monoton dan tidak membosankan, ketika pesan materi disampaikan.

\section{METODE PENELITIAN}

Desain penelitian yang digunakan untuk pembuatan media pembelajaran berupa animasi terintegrasi LCD projector layar sentuh dapat dilihat pada Gambar 1.

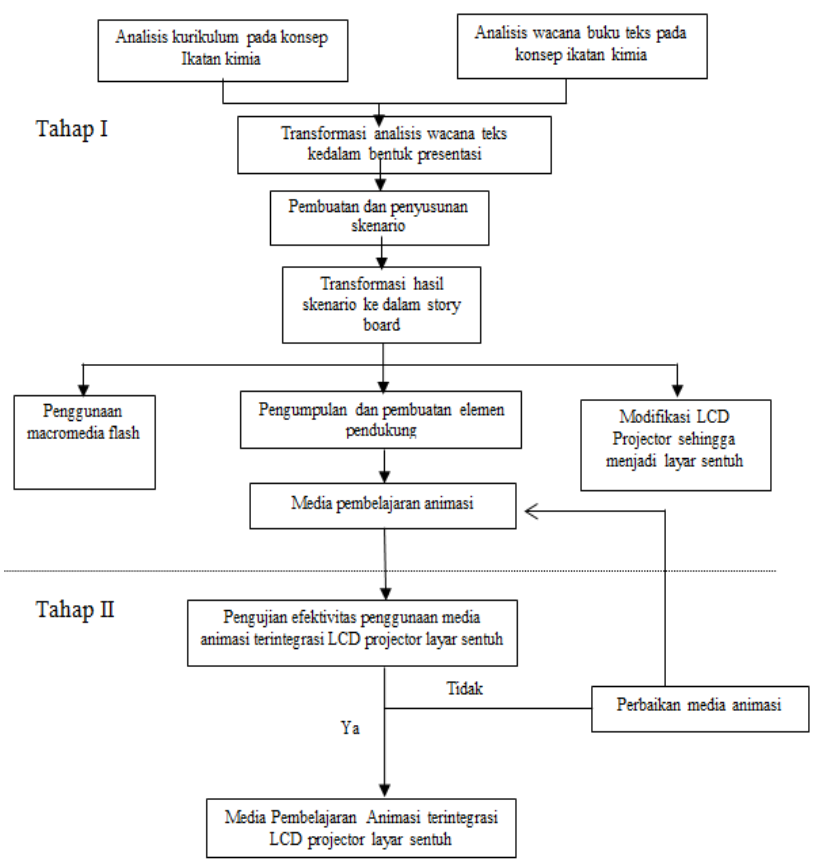

Gambar 1. Bagan Alur Penelitian

Tahapan pada alur diatas dapat diuraikan sebagai berikut:

Tahap I, perencanaan pembuatan media pembelajaran berupa media animasi: 1). Menganalisis kurikulum supaya media yang dibuat tidak melenceng dari kurikulum. 2). Menganalisis wacana buku teks dari berbagai sumber, seperti buku paket kimia SMA/MA kelas $X$ berdasarkan kurikulum mengenai konsep ikatan kimia serta dari sumber lain yang mendukung dengan tujuan menggali konsep yang akan dikembangkan. 3). Pembuatan skenario dan story board atau papan cerita, dimaksudkan agar mempermudah pembacaan isi cerita secara visual. 4). pembuatan media pembelajaran dalam bentuk media animasi menggunakan program aplikasi macromedia flash 8 professional. Pembuatan media ini menuntut berbagai presentasi visual atau grafis. Pembuatan gambar vector dengan menggunakan aplikasi coreldraw X6. 5). Modifikasi LCD projector layar sentuh digunakan untuk menciptakan komunikasi yang efektif, yaitu layar projector yang dapat mengendalikan gambar dalam komputer dengan menyentuh permukaan panel tanpa menggunakan mouse atau keyboard, dengan memanfaatkan aplikasi dari wii remote, yang merupakan alat kontrol dalam permainan game console nintendo wii. Dalam aplikasinya wii remote berfungsi untuk menangkap gerakan dari pena infra merah (IR Pen) dan mengkoneksikannya ke komputer dengan bantuan bluetooth. Pena infra merah berfungsi 
sebagai pengontrol pengganti mouse yang bisa langsung digunakan di atas tampilan layar. LCD projector layar sentuh mempunyai fungsi dan kegunaan yang sama dengan smartboard yang sudah ada sekarang ini.

Tahap II, pengujian efektivitas penggunaan media animasi; Media pembelajaran dalam bentuk animasi terintegrasi LCD projector layar sentuh yang telah dihasilkan, diujikan kepada siswa kelas $X$. Uji pre-test, post-test dan angket siswa kemudian dianalisis untuk mengetahui efektivitas penggunaan media apabila hasilnya tidak signifikan, maka dilakukan perbaikan berdasarkan respon siswa. Sehingga dihasilkan media pembelajaran animasi berbasis komputer yang dapat digunakan dalam proses pembelajaran ikatan kimia di kelas.

\section{HASIL DAN PEMBAHASAN}

Tahapan proses pemproduksian media animasi dilakukan secara sistematis dan berkesinambungan, supaya dihasilkan media pembelajaran yang benar-benar efektif ketika diaplikasikan dan digunakan dalam proses pembelajaran. Tahapan proses pemproduksian media pembelajaran meliputi, analisis wacana buku teks, identifikasi elemen media, transformasi hasil analisis wacana ke dalam bentuk presentasi, pembuatan skenario, dan penggabungan seluruh elemen media menggunakan program aplikasi macromedia flash 8 professional. Software aplikasi yang dihasilkan kemudian diintegrasikan dengan LCD projector layar sentuh untuk digunakan dalam pembelajaran konsep ikatan kimia di kelas.

Pengujian dilakukan terhadap siswa kelas $\mathrm{X}$ Madrasah Aliyah Negeri Insan Cendekia Paser (N =28).

\section{Tabel 1. Hasil Uji Efektifitas Media}

\begin{tabular}{|c|c|c|c|c|c|}
\hline \multirow{2}{*}{$\begin{array}{c}\text { Konsep/sub } \\
\text { konsep }\end{array}$} & \multicolumn{2}{|c|}{ Pre-test } & \multicolumn{2}{|c|}{ Post-test } & \multirow{2}{*}{$\begin{array}{l}\mathrm{N}- \\
\text { gain }\end{array}$} \\
\hline & M & SD & M & SD & \\
\hline Ikatan Ion & 61 & 16 & 72 & 16 & 0,3 \\
\hline Ikatan Kovalen & 77 & 3,0 & 86 & 9,0 & 0,4 \\
\hline $\begin{array}{l}\text { Bentuk } \\
\text { Molekul }\end{array}$ & 43 & 19 & 84 & 8,0 & 0,7 \\
\hline $\begin{array}{l}\text { Kepolaran } \\
\text { Senyawa }\end{array}$ & 77 & 4,0 & 85 & 5,0 & 0,3 \\
\hline Rata - Rata & 64,50 & 10,50 & 81,75 & 9,50 & 0,43 \\
\hline
\end{tabular}

(M: mean, SD: standar deviasi)
Berdasarkan Tabel 1. di atas, dapat diinterpretasikan bahwa terdapat peningkatan pemahaman siswa terbukti dengan peningkatan skor rerata (M) pre-test terhadap rerata (M) post test dengan rerata $\mathrm{N}$-gain sebesar 0,43 kategori sedang. Skor $\mathrm{N}$-gain terkecil atau nilai dibawah rerata diperoleh pada konsep ikatan ion dan kepolaran senyawa yaitu sebesar 0,3 dari rerata $\mathrm{N}$ gain 0,43 . Sementara itu skor $\mathrm{N}$-gain tertinggi diatas rerata diperoleh pada konsep bentuk molekul yaitu sebesar 0,7. Sedangkan konsep ikatan kovalen memperoleh skor $\mathrm{N}$-gain 0,4 dengan kategori sedang.

Konsep ikatan ion, ikatan kovalen, bentuk molekul dan kepolaran senyawa, sesungguhnya merupakan konsep abstrak yang terkadang siswa sulit untuk memahaminya. Dengan memvisualisaikan (teknik animasi) pada konsep tersebut, dapat memperlihatkan hubungan yang terjadi pada tingkat submikroskopik dengan tingkat makroskopik. Menurut Sweller (dalam Tasker, 2006), tingkat kompleksitas informasi atau materi yang sedang dipelajari (muatan kognitif intrinsik), dapat diminimumkan melalui teknik penyajian materi yang baik. Ketika muatan kognitif intrinsic menjadi minimum, diikuit oleh muatan kognitif ekstrinsik (teknik penyajian materi), maka besar kemungkinan untuk terjadinya proses konstruksi (akuisisi skema) pengetahuan, sehingga memori kerja dapat mengorganisasikan, mengkonstruksi, mengkoding, mengelaborasi dan mengintegrasikan materi yang sedang dipelajari sebagai pengetahuan yang tersimpan dengan baik di memori jangka panjang. Penyajian secara audio visual dinilai mampu membantu siswa memahami konsep yang selama ini dianggap sulit. Menurut Mayer (1997), bahwa multimedia pembelajaran harus mempunyai beberapa prinsip dasar diantaranya: 1). Multiple representation principle. Penjelasan yang menuntut multi representasi baik visual maupun verbal. 2). contiguity principle. Penjelasan multimedia harus mempunyai keterhubungan yang sesuai. 3). split attentionprinciple. Kata-kata yang disajikan secara auditori lebih baik dari pada secara visual berupa teks dalam layar. Dibawah ini adalah grafik yang menunjukan rerata peningkatan pre-test terhadap post-test. 


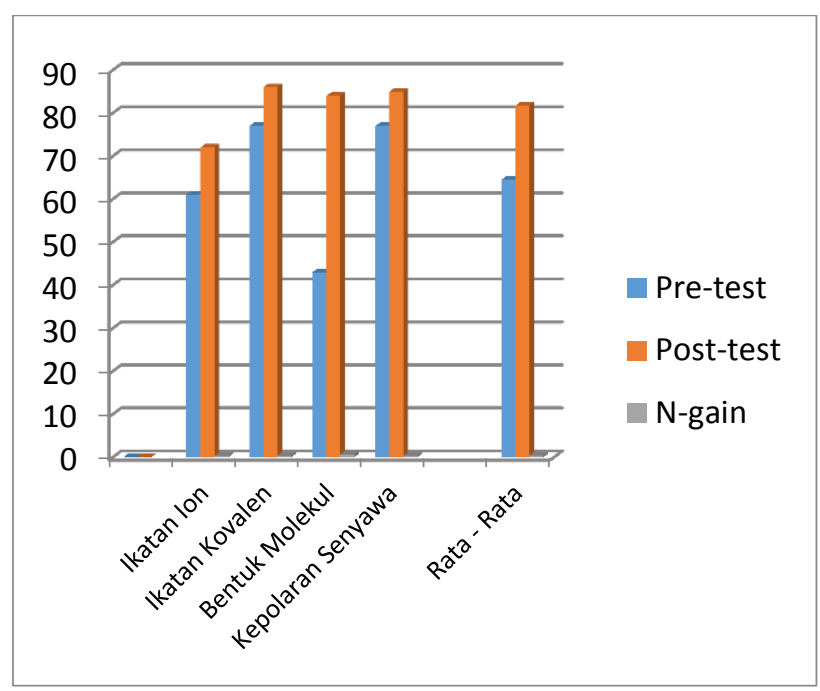

Gambar 2. Grafik rerata skor pre-tes dan post-test

Media animasi terintegrasi LCD projector layar sentuh dapat memperjelas penyajian pesan dan informasi, sehingga dapat memperlancar dan meningkatkan proses dan hasil belajar. Selain itu juga dapat mengarahkan perhatian siswa sehingga dapat menimbulkan motivasi belajar, dan memungkinkan untuk belajar sendiri-sendiri sesuai dengan kemampuan dan minatnya (student centered learning). Agar proses belajar mengajar dapat berhasil dengan baik, siswa sebaikanya diajak untuk memanfaatkan semua alat inderanya. Semakin banyak alat indera yang digunakan untuk menerima dan mengolah informasi semakin besar kemungkinan informasi tersebut dimengerti dan dapat dipertahankan dalam ingatan (Azhar, 2002). Media pembelajaran berupa animasi didasarkan pada kemampuannya menggabungkan berbagai media seperti teks, gambar, audio dan video. Teori pemrosesan informasi menjelaskan bagaimana suatu informasi diolah dan diintegrasikan dalam memori. Lebih lanjut Jhonstone dan Mayer (dalam Tasker, 2008:148) memberikan penjelasan mengenai system pemrosesan informasi ketika siswa belajar dari suatu multimedia interaktif. Berdasarkan teori koding ganda (dual coding theory) Paivio dan teori beban kognitif (cognitive load theory) Sweller, menjelaskan bahwa penggabungan informasi visual dan verbal secara teratur dapat mengefisienkan ketika pemanggilan kembali dan mentransfernya pada keadaan yang berbeda. Hasil signifikan diperoleh bahwa kapasitas memori kerja diperluas ketika penggabungan indera digunakan untuk memperoleh informasi.
Penggunaan media animasi terintegrasi LCD projector layar sentuh sebagai media pembelajaran digunakan sebagai upaya menjembatani siswa memahami konsep abstrak. Sementara itu diperoleh tangggapan siswa mengenai pembelajaran ikatan kimia dengan animasi terintegrasi LCD projector layar sentuh seperti yang ditunjukan pada tabel dibawah ini.

\section{Tabel 2. Tanggapan siswa terhadap media} animasi ikatan kimia

\begin{tabular}{|c|c|c|c|c|c|}
\hline \multirow{2}{*}{ No } & \multirow{2}{*}{ Uraian } & \multicolumn{4}{|c|}{ Persentase } \\
\hline & & SS & $\mathbf{S}$ & TS & STS \\
\hline 1 & $\begin{array}{l}\text { Saya senang belajar } \\
\text { kimia dengan } \\
\text { menggunakan } \\
\text { media animasi } \\
\text { terintegrasi LCD } \\
\text { Projektor layar } \\
\text { sentuh. }\end{array}$ & 61.54 & 38.46 & & \\
\hline 2 & $\begin{array}{l}\text { Saya lebih aktif } \\
\text { selama proses } \\
\text { pembelajaran } \\
\text { menggunakan } \\
\text { media animasi } \\
\text { terintegrasi LCD } \\
\text { Projektor layar } \\
\text { sentuh. }\end{array}$ & 54.55 & 36.36 & 9.09 & \\
\hline 3 & $\begin{array}{l}\text { Saya lebih } \\
\text { memperhatikan } \\
\text { materi pelajaran } \\
\text { selama proses } \\
\text { pembelajaran } \\
\text { dengan } \\
\text { menggunakan } \\
\text { media animasi } \\
\text { terintegrasi LCD } \\
\text { Projektor layar } \\
\text { sentuh. }\end{array}$ & 58.33 & 33.33 & 8.33 & \\
\hline 4 & $\begin{array}{l}\text { Saya lebih tertarik } \\
\text { mempelajarai } \\
\text { materi ikatan kimia } \\
\text { dengan } \\
\text { menggunakan } \\
\text { media animasi } \\
\text { terintegrasi LCD } \\
\text { Projektor layar } \\
\text { sentuh. }\end{array}$ & 72.73 & 18.18 & 9.09 & \\
\hline 5 & $\begin{array}{l}\text { Pembelajaran } \\
\text { ikatan kimia } \\
\text { dengan } \\
\text { menggunakan } \\
\text { media animasi } \\
\text { terintegrasi LCD } \\
\text { Projektor layar } \\
\text { sentuh membuat } \\
\text { Saya lebih } \\
\text { memahami materi } \\
\text { ikatan kimia. }\end{array}$ & 38.46 & 53.85 & 7.69 & \\
\hline 6 & Selama & 16.67 & 66.67 & 16.67 & \\
\hline
\end{tabular}




\begin{tabular}{|c|c|c|c|c|}
\hline & $\begin{array}{l}\text { pembelajaran } \\
\text { ikatan kimia Saya } \\
\text { selalu menanyakan } \\
\text { hal-hal yang belum } \\
\text { saya ketahui. }\end{array}$ & & & \\
\hline 7 & $\begin{array}{l}\text { Saya lebih berani } \\
\text { mengeluarkan ide } \\
\text { atau pendapat } \\
\text { selama proses } \\
\text { pembelajaran } \\
\text { dengan } \\
\text { menggunakan } \\
\text { media animasi } \\
\text { terintegrasi LCD } \\
\text { Projektor layar } \\
\text { sentuh. }\end{array}$ & 25.00 & 50.00 & 25.00 \\
\hline 8 & $\begin{array}{l}\text { Media animasi } \\
\text { terintegrasi LCD } \\
\text { Projektor layar } \\
\text { sentuh } \\
\text { menimbulkan } \\
\text { banyak pertanyaan, } \\
\text { karena ditayangkan } \\
\text { beberapa gambar } \\
\text { yang menarik. }\end{array}$ & 50.00 & 33.33 & 16.67 \\
\hline 9 & $\begin{array}{l}\text { Menurut Saya, } \\
\text { media animasi } \\
\text { terintegrasi LCD } \\
\text { Projektor layar } \\
\text { sentuh sangat } \\
\text { menarik karena } \\
\text { dapat } \\
\text { memunculkan ide- } \\
\text { ide dan pertanyaan. }\end{array}$ & 66.67 & 25.00 & 8.33 \\
\hline 10 & $\begin{array}{l}\text { Saya lebih antusias } \\
\text { mempelajari ikatan } \\
\text { kimia } \\
\text { menggunakan } \\
\text { media animasi } \\
\text { terintegrasi LCD } \\
\text { Projektor layar } \\
\text { sentuh karena } \\
\text { disajikan dengan } \\
\text { menampilkan } \\
\text { animasi yang } \\
\text { menarik. }\end{array}$ & 75.00 & 16.67 & 8.33 \\
\hline 11 & $\begin{array}{l}\text { Interaksi antara } \\
\text { media animasi } \\
\text { dengan materi } \\
\text { pelajaran lebih aktif } \\
\text { karena } \\
\text { diintegrasikan } \\
\text { dengan LCD } \\
\text { Projektor layar } \\
\text { sentuh }\end{array}$ & 53.85 & 46.15 & \\
\hline 12 & $\begin{array}{l}\text { Sebaiknya konsep- } \\
\text { konsep ikatan kimia } \\
\text { disajikan dengan } \\
\text { animasi sehingga } \\
\text { pembelajaran } \\
\text { menjadi menarik. }\end{array}$ & 75.00 & 25.00 & \\
\hline & Rata-rata & 53.98 & 36.92 & 12.13 \\
\hline
\end{tabular}

Keterangan :SS: sangat setuju, S: setuju, TS: tidak setuju, STS: sangat tidak setuju

Tanggapan siswa mengenai pembelajaran ikatan kimia menggunakan animasi terintegrasi LCD layar sentuh menunjukan bahwa: secara umum siswa merasa sangat senang ketika pembelajaran menggunakan animasi yaitu sebesar $95,45 \%$. Perhatian siswa menjadi focus terhadap materi yang sedang dipelajari yaitu rata-rata sebesar $87.82 \%$. Rasa ingin tahu siswa rata-rata sebesar 87,5\%. Dan keterlibatan siswa dalam proses pembelajaran atau antusiasme siswa mengikuti pembelajaran yaitu rata-rata sebesar $86.11 \%$. Tanggapan siswa mengenai kualitas media, secara umum memperoleh tanggapan positif. Sehingga media yang dibuat layak digunakan untuk membantu proses pembelajaran di kelas. Tampilan grafis dalam suatu multimedia bertujuan untuk memvisualisasikan konsep yang ingin disampaikan kepada siswa, dan bentuk tampilan yang menarik bagi siswa dapat membangkitkan minat dan perhatian. Namun demikian masih terdapat kekurangan yaitu sebesar $25 \%$ siswa siswa masih ragu mengeluarkan ide dan pendapatnya ketika pembelajaran dikelas, sehingga perbaikan metode dan media pembelajaran animasi terintegrasi projector layar sentuh masih harus dilakukan.

\section{KESIMPULAN}

Berdasarkan hasil pembuatan software media animasi terintegrasi LCD projector layar sentuh yang diaplikasikan pada pembelajaran kimia konsep ikatan kimia, dapat ditarik simpulan sebagai berikut: 1). Proses pembuatan animasi, tahap pertama adalah menganalisis wacana buku teks, kemudian diubah kedalam bentuk materi presentasi. Tahap selanjutnya merupakan pengintegrasian seluruh elemen media dengan menggunakan software aplikasi, sehingga dihasilkan media animasi. Animasi yang dihasilkan kemudian diaplikasikan dalam pembelajaran kimia diintegrasikan dengan LCD projector layar sentuh sehingga tercipta komunikasi dan interaksi yang efektif. 2). Bentuk visualisasi yang digunakan dalam media ini adalah teks, grafis, dan animasi yang didasarkan pada keterampilan intelektual. 3). Media animasi terintegrasi LCD projector dapat meningkatkan pemahaman dan minat siswa kelas $X$ Madrasah Aliyah Negeri Insan Cendekia Paser pada konsep ikatan kimia. 


\section{DAFTAR PUSTAKA}

Chittleborough, Gail D et all. (2002). "Constrain to the development of first year university chemistry student's mental model of chemical phenomena", Theaching and Learning Forum 2002: Focusing on the Student.

Azhar, Arsyad. (2002). Media Pembelajaran. Jakarta: Rajawali press

Tasker, Roy dan Dalton, Rebecca. (2006). Research into Practice: Visualization of the Molecular World Using Animation. Journal of Chemistry Education Research and Practice, 7(2), 141-159.

Mayer, RE dan Moreno, Roxana. (1997). A cognitive Theory of Multimedia Learning: Implication for Design Principles. Journal of educational technologies. (24), 345376.

Lee, Jhonny. (2013). Low-cost Multi-Point Interactive Whiteboard using the Wiimote. (http://johnnylee.net/projects/wii), diakses tanggal 20 Agustus 2013

Anonim. (2012). Chemical Bonds. (http://www.bcs.whfreeman.com/thelifewir e/content/chp02/0201s.swf), diakses tanggal 5 April 2012.

Anonim. (2012). lonic Bonds. (http://g.web.umkc.edu/gounevt/Animatio ns/Animations211/lonicvsCovalentBonds.s wf), diakses tanggal 5 April 2012. 